\title{
ANALISIS TINGKAT BAHAYA, KERENTANAN DAN RISIKO PERUBAHAN IKLIM: STUDI KOMPARATIF PETANI PADI JAWA BARAT DAN JAWA TIMUR
}

\author{
ANALYSIS OF CLIMATE CHANGE HAZARDS, VULNERABILITY \\ AND RISK LEVEL: A COMPARATIVE STUDY OF RICE FARMERS \\ IN WEST JAVA AND EAST JAVA
}

\author{
Bobby Rachmat Saefudin*1 , Tuhpawana Priatna Sendjaja ${ }^{2}$, Dini Rochdiani ${ }^{2}$, Ronnie \\ Susman Natawidjaja ${ }^{2}$, Elly Rasmikayati ${ }^{2}$
}

${ }^{1}$ Fakultas Pertanian, Ma'soem University, J1. Raya Cipacing No. 22 Jatinangor, 45363

${ }^{2}$ Fakultas Pertanian, Universitas Padjadjaran, Jl. Ry Bandung-Sumedang KM.21 Jatinangor, 45363

*E-mail corresponding: bobbyrachmat@masoemuniversity.ac.id

(Diterima 9-1-2021; Disetujui 18-1-2021)

\begin{abstract}
ABSTRAK
Dampak perubahan iklim terhadap sektor pertanian terutama komoditas padi telah sangat terasa. Petani padi di Indonesia yang sebagian besar merupakan petani kecil tentunya menjadi pihak pertama yang terkena dampak dari risiko perubahan iklim. Penelitian bertujuan untuk menganalisis dan membandingkan tingkat bahaya, kerentanan dan risiko perubahan iklim pada petani padi di Jawa Barat dan Jawa Timur. Penelitian ini menggunakan total 600 orang petani dari Jawa Barat dan Jawa Timur yang ditentukan menggunakan teknik sampling acak stratifikasi banyak tahap. Teknik analisis data yang digunakan adalah model analisis tingkat bahaya, kerentanan dan risiko perubahan iklim serta uji Mann-Whitney U. Hasil penelitian menunjukkan bahwa petani padi di Jawa Barat memiliki tingkat bahaya perubahan iklim yang lebih besar secara signifikan ketimbang petani padi di Jawa Timur, namun tingkat kerentanan perubahan iklim petani padi di Jawa Barat secara signifikan lebih rendah dibandingkan petani padi di Jawa Timur. Hasil analisis tingkat risiko perubahan iklim menunjukkan bahwa tidak terdapat perbedaan yang signifikan antara petani Jawa Barat dan Jawa Timur dalam hal tingkat risiko perubahan iklimnya. Keduanya sama-sama memiliki tingkat risiko perubahan iklim yang berada pada kategori rendah hingga sedang.
\end{abstract}

Kata kunci: tingkat bahaya, tingkat kerentanan, tingkat risiko, eksposur, sensitifitas, kapasitas adaptasi, perubahan iklim, petani padi

\section{ABSTRACT}

The impact of climate change on the agricultural sector, especially rice, has been very pronounced. Rice farmers in Indonesia who are mostly small farmers, are certainly the first to be affected by the risks of climate change. The study aims to analyze and compare the level of climate change hazard, vulnerability and risk to rice farmers in West Java and East Java. This study used a total of 600 farmers from West Java and East Java who were determined using a multistage stratified random sampling technique. The data analysis technique used was the analysis model for the climate change hazard, vulnerabilityy and risk level and the Mann-Whitney U test. The results showed that rice farmers in West Java had a significantly greater level of climate change hazards than rice farmers in East Java, but the level of climate change vulnerability for rice farmers in West Java is significantly lower than that of rice farmers in East Java. The results of climate change risk level analysis show that there is no significant difference between West Java and East Java farmers in terms of the level of climate change risk. Both have low to moderate levels of climate change risk.

Keywords: hazard level, vulnerability level, risk level, exposure, sensitivity, adaptive capacity, climate change, rice farmers 


\section{PENDAHULUAN}

Dampak perubahan iklim pada sektor pertanian telah dapat dirasakan dan telah terjadi di Indonesia. Hal tersebut antara lain diindikasikan oleh beberapa fenomena alam yang sering terjadi seperti bencana banjir, musim kemarau yang panjang dan curah hujan ekstrim (Sudarma dan As-syakur, 2018; Rasmikayati dkk., 2020). Merujuk kepada Ruminta (2015), dampak sosial ekonomi yang diakibatkan oleh perubahan iklim yaitu: 1) Menurunnya produktivitas dan produksi; 2) Menurunnya kontribusi sektor pertanian pada GDP nasional; 3) Befluktuasi harga produk pertanian di pasar global; 4) Berubahnya distribusi geografis dari rezim perdagangan; dan 5) Meningkatnya jumlah penduduk sehingga meningkatkan pula risiko kelaparan dan ketidakamanan pangan.

Menurut Beck dan Mahony (2018), perubahan iklim secara tidak langsung berpengaruh pada menurunnya produksi pangan dunia, seperti yang terjadi melalui konversi dari lahan pangan ke industri, di mana hal ini mengakibatkan naiknya harga bahan makanan karena porsinya menurun. Naik turunnya supply produksi pertanian sangat bergantung pada iklim dan cuaca. Pengaruh perubahan iklim terhadap sektor perdagangan komoditas pertanian bergantung kepada beberapa hal diantarnya: (1) jumlah produksi pertanian nasional, (2) Keseimbangan produk yang dipasarkan di dalam negeri dan yang diekspor ke luar, dan (3) struktur dari produksi pertanian itu sendiri (Handoko dkk., 2008).

Setiani (2020) memprediksikan kemungkinan terjadinya risiko bencana kelaparan di daerah tropis apabila terjadi kenaikan suhu rata-rata dunia antara 1-2 ${ }^{0} \mathrm{C}$ yang menyebabkan penurunan produktivitas pertanian. Intensitas kekeringan dan banjir yang terus meningkat diperkirakan akan memberikan pengaruh buruk pada produksi lokal, khususnya pada sentra produksi pangan di daerah subtropis dan tropis. Perubahan musim di mana musim kemarau menjadi lebih panjang dan cenderung kering dengan trend hujan makin turun sehingga menyebabkan gagal panen, krisis air bersih dan kebakaran hutan.

Variasi iklim yang tidak beraturan tersebut sangat erat kaitannya dengan kejadian iklim ekstrim atau yang biasa disebut ENSO (El Nino Southern Oscillation). Hubungan antara fenomena El Nino dengan produksi padi di Indonesia ditunjukkan pada Gambar 1 . 


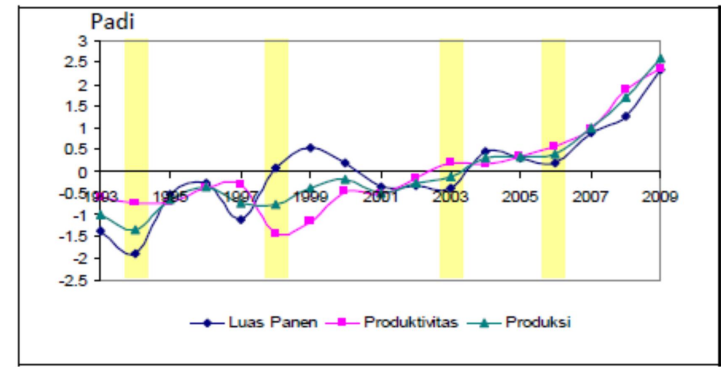

Gambar 1. Grafik Luas Panen, Produksi dan Produktivitas Padi di Indonesia Kurun Waktu 1993-2009 (Garis kuning menunjukkan tahun kejadian El Nino). Sumber: Ruminta (2011)

Sejalan dengan hal tersebut, Handoko dkk. (2008) menyatakan bahwa pola musim mulai tidak beraturan sejak 1991 dengan indikasi terjadinya pergeseran musim dan perubahan pola hujan mengganggu swasembada pangan nasional hingga kini tergantung impor pangan terutama beras. Dalam beberapa tahun terakhir ini pergeseran musim hujan menyebabkan bergesernya musim tanam dan panen komoditi pangan seperti padi, palawija dan sayuran (Rasmikayati dkk., 2017), sedangkan banjir dan kekeringan menyebabkan gagal tanam, gagal panen, dan bahkan menyebabkan puso (Rochdiani dkk., 2017). Hal ini berimplikasi pada penurunan produksi dan pendapatan petani (Saefudin, 2014).

Dampak perubahan iklim terhadap sektor pertanian terutama komoditas padi telah sangat terasa, hal ini dibuktikan oleh beberapa penelitian diantaranya Sumastuti dan Pradono (2016); Nuraisah dan Kusumo (2019); Cahyaningtyas dkk.
(2019); dan Rasmikayati dan Djuwendah (2015). Petani padi di Indonesia sebagian besar merupakan petani kecil dengan kepemilikan lahan dan modal yang minim (Natawidjaja dkk., 2009) yang tentunya merupakan pihak pertama yang akan terkena dampak dari risiko perubahan iklim.

Model analisis risiko perubahan iklim terhadap sektor pertanian secara kuantitatif dilakukan oleh Gommes (1998). Dia mendefinisikan risiko sebagai "kerugian/kehilangan (loss)" atau dengan bahasa statistiknya "peluang terjadinya kejadian yang berbahaya”. Kemudian, dia memformulasikan risiko (risk) berdasarkan frekuensi kerugian dan kerentanan (vulnerability) dari perubahan iklim pada produksi pertanian.

Pada perkembangannya, Crichton (1999) memberikan definisi dari risiko (risk) yaitu fungsi dari peluang kerugian/kehilangan dan tergantung kepada 3 elemen yaitu bahaya (hazard) dan kerentanan (vulnerability) dan eksposur (exposure). Kemudian Affeltranger el al (2006) membuat pemodelan tingkat risiko sebagai fungsi matematis dari bahaya (hazard) dan kerentanan (vulnerability). Sedangkan Kerentanan sendiri menurut IPCC (2001) merupakan fungsi dari eksposur 
(exposure), sensitivitas (sensitivity) dan kapasitas adaptasi (adaptive capacity).

Penelitian bertujuan untuk menganalisis dan membandingkan tingkat bahaya (hazard), kerentanan (vulnerability) dan risiko (risk) perubahan iklim pada petani padi di Jawa Barat dan Jawa Timur.

\section{METODE PENELITIAN}

\section{Objek dan Tempat Penelitian}

Objek dalam penelitian ini adalah tingkat bahaya (hazard) perubahan iklim, tingkat kerentanan (vulnerability) perubahan iklim dan tingkat risiko (risk) perubahan iklim pada petani padi di Jawa Barat dan Jawa Timur. Provinsi Jawa Barat dan Jawa Timur diambil sebagai tempat penelitan karena kedua provinsi tersebut merupakan dua kontributor terbesar produksi padi di Indonesia dengan total kontribusi mencapai 32,53\% terhadap produksi padi nasional pada tahun 2015.

Di lain pihak, kedua provinsi tersebut merupakan dua provinsi yang mengalami kejadian-kejadian bencana alam terbanyak sehingga kedua provinsi ini juga mengalami kejadian gagal panen terbesar di Indonesia. Di samping itu, juga kedua provinsi ini berpenduduk sangat padat sehingga sebagian besar petani padi di kedua provinsi ini merupakan petani kecil dengan penguasaan lahan pertanian yang sempit yang berimbas pada kecilnya pendapatan usahatani mereka.

\section{Desain Penelitian}

Desain penelitian yang digunakan pada penelitian ini adalah explanatory design yang menggunakan a two-phase mixed method (Creswell dan Clark, 2017). Fase pertama pada desain ini dimulai dengan pengumpulan dan analisis data kuantitatif, kemudian pada fase berikutnya dilakukan pengumpulan dan analisis tambahan terhadap data kualitatif. Model explanatory design yang digunakan adalah Follow up explanations model (Creswell dan Clark, 2017). Pada model ini peneliti mengidentifikasi temuan-temuan khusus kuantitatif yang membutuhkan penjelasan tambahan, misalnya perbedaan statistik dalam kelompok, yang menempati tingkatan skor ekstrim, atau hasil yang tidak terprediksikan. Berdasarkan pada temuan-temuan khusus tersebut peneliti mengumpulkan data kualitatif melalui diskusi dengan beberapa informan kunci (petani) untuk menindaklanjuti temuantemuan khusus berdasarkan hasil 
pengumpulan data kuantitatif sebelumnya (Creswell dan Clark, 2017).

\section{Jenis dan Sumber Data}

Data yang digunakan dalam penelitian ini adalah data primer yang dikumpulkan oleh Pusat Riset Pangan Berkelanjutan yang diolah kembali untuk desain penelitian ini. Data primer tersebut diperoleh dari pengumpulan data dengan cara interview (wawancara langsung) dengan petani dengan menggunakan kuesioner. Sebagai penunjang, digunakan data sekunder yang berkaitan dengan desain penelitian. Data sekunder tersebut berasal dari BPS, hasil penelitian sebelumnya, internet, Dinas Pertanian, Badan Meteorologi Klimatologi dan Geofisika serta Badan Nasional Penanggulangan Bencana.

\section{Populasi, Sampel dan Sampling}

Populasi dari penelitian ini adalah seluruh petani padi di Jawa Barat dan Jawa Timur. Berdasarkan informasi dari sumber data yang digunakan dalam penelitian ini, total responden yang terpilih adalah 600 orang petani, 300 petani dari Jawa Barat dan 300 petani dari Jawa Timur. Responden dipilih dengan menggunakan teknik sampling acak banyak tahap (muti-stage random sampling). Lokasi yang dipilih adalah dua provinsi utama sentra padi di Indonesia, yaitu Provinsi Jawa Barat dan Jawa Timur.

Dari masing-masing provinsi dipilih 3 kabupaten secara random dengan pembobotan (relative importance) jumlah produksi padi tinggi dan jumlah kejadian bencana tinggi. Selanjutnya, dari setiap kabupaten dipilih 2 kecamatan secara random. Kemudian dari masing-masing kecamatan dipilih 1 desa secara random. Sedemikian rupa sehingga dari proses tersebut diperoleh cakupan daerah penelitian yang meliputi 2 provinsi, 6 kabupaten, 12 kecamatan dan 12 desa. Cakupan dari daerah penelitian ini didesain untuk cukup mewakili keragaman dinamis kondisi wilayah sentra produksi padi utama di Indonesia secara umum dengan kerentanan (vulnerability) wilayah terhadap kejadian bencana yang tinggi.

\section{Rancangan Analisis Data}
1. Tingkat
Bahaya
(Hazard)

\section{Perubahan Iklim Petani}
Indikator tingkat bahaya (hazard) perubahan iklim petani yang digunakan dalam penelitan ini adalah penurunan produktivitas hasil panen petani yang didefinisikan sebagai produksi petani 
yang hilang per luas lahan panen (farmer's loss of productivity) yang merupakan bahaya akibat perubahan iklim (Ruminta, 2011), dan dirumuskan sebagai berikut:

$$
\begin{aligned}
& H_{i}=\left|\frac{P r_{i}-P r_{\text {max }}}{P r_{\max }}\right| \\
H_{i}= & \text { Tingkat hazard (bahaya) } \\
& \text { produksi yang hilang dari } \\
& \text { petani- } i, \\
P r_{i}= & \text { Produktivitas petani- } i, \\
P r_{\text {max }}= & \text { Produktivitas petani yang } \\
& \text { tertinggi. }
\end{aligned}
$$

\section{Tingkat Kerentanan (Vulnerability)}

\section{Perubahan Iklim Petani}

Indikator tingkat kerentanan petani terhadap perubahan iklim mengadaptasi dari Li et al (2010) dengan modifikasi. Setiap indikator diberikan skor yang mencerminkan tingkat kerentanan petani. Skor ini menunjukkan skala dari nilai yang "buruk" sampai pada nilai "baik". Nilai "buruk" mencerminkan kondisi yang paling rentan bagi petani terhadap perubahan iklim. Sebaliknya nilai "baik" mencerminkan kondisi yang paling tidak rentan. Skor untuk variabel kualitatif ditentukan berdasarkan "scientific judgement" dari pembuat skor. Skor untuk variabel kuantitatif ditentukan berdasarkan interval kelas dari data seluruh petani (Jawa Barat dan Jawa Timur) mengenai indikator tersebut, hal ini mengacu kepada Rygel et al (2006).

Dalam penelitian ini, skor untuk setiap indikator dari dimensi eksposur dan sensitivitas dibuat empat skor yaitu “0” untuk kategori paling tidak rentan (baik) sampai “3" untuk yang paling rentan (buruk). Sedangkan untuk setiap indikator kapasitas adaptasi dibuat tiga skor yaitu "1" untuk kategori paling rentan (buruk) sampai “3” untuk kategori paling tidak rentan (baik). Penentuan skor "1" sebagai skor terkecil kapasitas adaptasi ini disesuaikan dengan domain (daerah asal) fungsi kerentanan dimana nilai dari kapasitas adaptasi ini tidak boleh sama dengan nol. Pada Tabel 4. disajikan indikator-indikator kerentanan dan skor yang digunakan untuk menilai kerentanan petani terhadap perubahan iklim. 
Tabel 1. Indikator Kerentanan dan Skor yang Digunakan untuk Menilai Kerentanan Petani terhadap Perubahan Iklim

\begin{tabular}{|c|c|c|c|c|c|}
\hline $\begin{array}{c}\text { Dimensi } \\
\text { Kerentanan }\end{array}$ & Indikator (Variabel) & Skor & Baik & Buruk & Keterangan \\
\hline \multirow[t]{4}{*}{$\begin{array}{l}\text { Eksposur } \\
\text { (exposure) }\end{array}$} & Jenis varietas padi & $0 ; 1 ; 2 ; 3$ & 0 & 3 & $\begin{array}{l}\text { (0) Hibrida; (1) Ciherang, IR 64; (2) } \\
\text { Membrano, Ketan; (3) Lainnya/tidak } \\
\text { tahu }\end{array}$ \\
\hline & Asal varietas padi & $0 ; 1 ; 2 ; 3$ & 0 & 3 & $\begin{array}{l}\text { (0) BBU/BBI, Toko saprodi; (1) } \\
\text { Penangkar; (2) Petani lain, Hasil } \\
\text { produksi sendiri; (3) Lainnya/tidak } \\
\text { tahu }\end{array}$ \\
\hline & $\begin{array}{l}\text { Jumlah tanggungan } \\
\text { keluarga }\end{array}$ & $0 ; 1 ; 2 ; 3$ & 0 & 3 & $\begin{array}{l}(0)<2 \text { orang; (1) } 2-3 \text { orang; (2) } 4-5 \\
\text { orang; (3) } \geq 6 \text { orang }\end{array}$ \\
\hline & $\begin{array}{l}\text { Intensitas serangan } \\
\text { hama }\end{array}$ & $0 ; 1 ; 2 ; 3$ & 0 & 3 & $\begin{array}{l}\text { (0) Tidak pernah; (1) Jarang; (2) } \\
\text { Hanya pada salah satu musim tanam; } \\
\text { (3) Sering/setiap musim tanam }\end{array}$ \\
\hline \multirow[t]{4}{*}{$\begin{array}{l}\text { Sensitivitas } \\
\text { (sensitivity) }\end{array}$} & $\begin{array}{l}\text { Total biaya tenaga } \\
\text { kerja dalam satu } \\
\text { musim tanam }\end{array}$ & $0 ; 1 ; 2 ; 3$ & 0 & 3 & $\begin{array}{l}\text { (0) interval kelas pertama; (1) } \\
\text { interval kelas kedua; (2) interval } \\
\text { kelas ketiga; (3) interval kelas } \\
\text { keempat }\end{array}$ \\
\hline & $\begin{array}{l}\text { Total biaya input } \\
\text { pertanian dalam } \\
\text { satu musim tanam }\end{array}$ & $0 ; 1 ; 2 ; 3$ & 0 & 3 & $\begin{array}{l}(0) \text { interval kelas pertama; (1) } \\
\text { interval kelas kedua; (2) interval } \\
\text { kelas ketiga; (3) interval kelas } \\
\text { keempat }\end{array}$ \\
\hline & Biaya irigasi & $0 ; 1 ; 2 ; 3$ & 0 & 3 & $\begin{array}{l}\text { (0) interval kelas pertama; (1) } \\
\text { interval kelas kedua; (2) interval } \\
\text { kelas ketiga; (3) interval kelas } \\
\text { keempat }\end{array}$ \\
\hline & $\begin{array}{l}\text { Harga jual yang } \\
\text { hilang }\end{array}$ & $0 ; 1 ; 2 ; 3$ & 0 & 3 & $\begin{array}{l}\text { (0) interval kelas pertama; (1) } \\
\text { interval kelas kedua; (2) interval } \\
\text { kelas ketiga; (3) interval kelas } \\
\text { keempat }\end{array}$ \\
\hline \multirow{8}{*}{$\begin{array}{l}\text { Kapasitas } \\
\text { adaptasi } \\
\text { (adaptive } \\
\text { capacity) }\end{array}$} & Usia & $1 ; 2 ; 3$ & 3 & 1 & $\begin{array}{l}\text { (1) interval kelas pertama; (2) } \\
\text { interval kelas kedua; (3) interval } \\
\text { kelas ketiga }\end{array}$ \\
\hline & Pengalaman & $1 ; 2 ; 3$ & 3 & 1 & $\begin{array}{l}\text { (1) interval kelas pertama; (2) } \\
\text { interval kelas kedua; (3) interval } \\
\text { kelas ketiga }\end{array}$ \\
\hline & Pelatihan tani & $1 ; 2 ; 3$ & 3 & 1 & $\begin{array}{l}\text { (1) interval kelas pertama; (2) } \\
\text { interval kelas kedua; (3) interval } \\
\text { kelas ketiga }\end{array}$ \\
\hline & Jam kerja & $1 ; 2 ; 3$ & 3 & 1 & $\begin{array}{l}\text { (1) interval kelas pertama; (2) } \\
\text { interval kelas kedua; (3) interval } \\
\text { kelas ketiga }\end{array}$ \\
\hline & Luas lahan & $1 ; 2 ; 3$ & 3 & 1 & $\begin{array}{l}\text { (1) interval kelas pertama; (2) } \\
\text { interval kelas kedua; (3) interval } \\
\text { kelas ketiga }\end{array}$ \\
\hline & Kesuburan lahan & $1 ; 2 ; 3$ & 3 & 1 & $\begin{array}{l}\text { (1) Kurang subur; (2) Subur; (3) } \\
\text { Sangat subur }\end{array}$ \\
\hline & Kondisi irigasi & $1 ; 2 ; 3$ & 3 & 1 & (1) Buruk; (2) Cukup; (3) Baik \\
\hline & $\begin{array}{l}\text { Pendapatan Luar } \\
\text { Tani }\end{array}$ & $1 ; 2 ; 3$ & 3 & 1 & $\begin{array}{l}\text { (1) interval kelas pertama; (2) } \\
\text { interval kelas kedua; (3) interval } \\
\text { kelas ketiga }\end{array}$ \\
\hline
\end{tabular}


Selanjutnya, setelah didapatkan skor untuk setiap indikator kerentanan, kemudian dihitung tingkat kerentanan petani terhadap perubahan iklim yang merupakan perkalian dari rata-rata skor eksposur dan sensitivitas dibagi rata-rata skor kapasitas adaptasi petani. Perhitungan tingkat kerentanan petani terhadap perubahan iklim ini menggunakan rumus yang diadaptasi dan dimodifikasi dari IPCC (2001) dan Ruminta (2011) sebagai berikut:

$$
V_{i}=\frac{\overline{E_{l}} \times \overline{S_{l}}}{\overline{A C_{l}}} \quad ; \overline{A C_{l}} \neq 0
$$

$V_{i}=$ Tingkat vulnerability (kerentanan) petani- $i$ terhadap perubahan iklim,

$\bar{E}_{l}=$ Tingkat eksposur (rata-rata skor eksposur) petani- $i$ terhadap perubahan iklim,

$\overline{S_{l}}=$ Tingkat sensitivitas (rata-rata skor sensitivitas) petani- $i$ terhadap perubahan iklim,

$\overline{A C_{l}}=$ Tingkat kapasitas adaptasi (ratarata skor kapasitas adaptasi) petani- $i$ terhadap perubahan iklim.

\section{Tingkat Risiko (Risk) Perubahan Iklim Petani}

Analisis risiko perubahan iklim pada petani mengadaptasi dari Affeltranger et. al. (2006) yang membuat pemodelan tingkat risiko sebagai fungsi matematis dari bahaya (hazard) dan kerentanan (vulnerability). Rumus tingkat risiko perubahan iklim pada petani adalah sebagai berikut:

$$
R_{i}=H_{i} \times V_{i}
$$

$R_{i}=$ Tingkat risiko (risk) petani- $i$ terhadap perubahan iklim,

$H_{i}=$ Tingkat bahaya (hazard) petani- $i$ terhadap perubahan iklim,

$V_{i}=$ Tingkat kerentanan (vulnerability) petani- $i$ terhadap perubahan iklim.

\section{Uji Hipotesis Non Parametrik:} Mann-Whitney U-Test

Mann-Whitney U-Test digunakan untuk menguji perbedaan tingkat bahaya, kerentanan dan risiko perubahan iklim antara petani Jawa Barat dan Jawa Timur. Mann-Whitney U-Test merupakan pengujian hipotesis untuk 2 sampel independen dengan metode non parametrik untuk variabel kualitatif dengan skala pengukuran ordinal. Langkah-langkahnya adalah sebagai berikut (Anderson et al, 2016):

a. Hipotesis

$\mathrm{H}_{0}$ : Tidak ada perbedaan tingkat bahaya/ tingkat kerentanan/tingkat risiko perubahan iklim antara petani Jawa Barat dan Jawa Timur

Ha: Terdapat perbedaan tingkat bahaya/ tingkat kerentanan/tingkat risiko perubahan iklim antara petani Jawa Barat dan Jawa Timur. 


\section{b. Statistik Uji}

Bentuk distribusi Mann-Whitney U-Test adalah mendekati distribusi normal baku (z) untuk kasus sampel besar $\left(n_{1}, n_{2} \geq 7\right)$ dengan statistic uji sebagai berikut:

$$
z=\frac{U-\mu_{U}}{\sigma_{U}}
$$

dengan

$$
\mu_{U}=\frac{n_{1} n_{2}}{2}
$$

dan

$$
\sigma_{U}=\sqrt{\frac{n_{1} n_{2}\left(n_{1}+n_{2}+1\right)}{12}}
$$

Keterangan:

$n_{1}=$ Ukuran sampel petani padi Jawa Barat,

$n_{2}=$ Ukuran sampel petani padi Jawa Timur,

$U=$ Jumlah peringkat dari data variabel yang diuji,

$\mu_{U}=$ Mean of sampling distribution of $U$

$\sigma_{U}=$ Standard deviation of sampling distribution of $U$.

c. Kriteria Penolakan $\mathrm{H}_{0}$

Tolak $\mathrm{H}_{0}$ jika $p$-value $\leq \alpha$

Proses analisis data dilakukan dengan menggunakan alat bantu software statistics SPSS 22.

\section{HASIL DAN PEMBAHASAN}

Tingkat Bahaya (Hazard) Perubahan Iklim pada Petani Padi di Jawa Barat dan Jawa Timur

Berdasarkan hasil analisis data sebagaimana tersaji pada Tabel 3, dapat disimpulkan bahwa setidaknya 70\% petani padi Jawa Barat memiliki tingkat bahaya perubahan iklim dalam kategori tinggi. Sementara petani padi Jawa Timur kebanyakannya memiliki tingkat bahaya perubahan iklim kategori sedang. Ratarata tingkat bahaya perubahan iklim pada petani Jawa Barat dan Jawa Timur secara berurutan adalah 0,73 dan 0,67. Simpangan baku tingkat bahaya perubahan iklim petani Jawa Barat lebih tinggi dari Jawa Timur, artinya tingkat bahaya perubahan iklim pada petani padi Jawa Barat lebih berfluktuatif ketimbang Jawa Timur.

\begin{tabular}{|c|c|c|c|c|}
\hline \multirow{2}{*}{$\begin{array}{l}\text { Tingkat Bahaya } \\
\text { Perubahan Iklim }\end{array}$} & \multicolumn{2}{|c|}{ Jawa Barat } & \multicolumn{2}{|c|}{ Jawa Timur } \\
\hline & $\mathrm{n}$ & $\%$ & $\mathrm{n}$ & $\%$ \\
\hline $\begin{array}{l}0<H_{i} \leq 0.33 \\
\text { (Rendah) }\end{array}$ & 1 & 0.33 & 2 & 0.67 \\
\hline $\begin{array}{l}0.25<H_{i} \leq \\
0.67 \text { (Sedang) }\end{array}$ & 67 & 22.33 & 168 & 56.00 \\
\hline $\begin{array}{l}0.67<H_{i} \leq 1 \\
\text { (Tinggi) }\end{array}$ & 232 & 77.33 & 130 & 43.33 \\
\hline Jumlah (n) & 300 & 100 & 300 & 100 \\
\hline Maksimum & \multicolumn{2}{|c|}{0.95} & \multicolumn{2}{|c|}{0.93} \\
\hline Minimum & \multicolumn{2}{|c|}{0.25} & \multicolumn{2}{|c|}{0.00} \\
\hline Rata-rata & \multicolumn{2}{|c|}{0.73} & \multicolumn{2}{|c|}{0.67} \\
\hline Simp. Baku & \multicolumn{2}{|c|}{0.09} & \multicolumn{2}{|c|}{0.10} \\
\hline p-value & \multicolumn{4}{|c|}{$0.000 * *$} \\
\hline $\begin{array}{r}\text { Ket: } * \text { Signifika } \\
* * \text { Signifika } \\
\text { sumber } \text { data prin }\end{array}$ & da & ff nyat & $\begin{array}{l}5 \% \\
1 \%\end{array}$ & \\
\hline
\end{tabular}

Tabel 2. Tingkat Bahaya (Hazard) Perubahan Iklim Petani Padi Jawa Barat dan Jawa Timur 
Hasil pengujian Mann Withney U menunjukkan bahwa dengan tingkat kepercayaan 99\%, tingkat bahaya perubahan iklim pada populasi petani padi Jawa Barat lebih tinggi dari pada populasi petani padi Jawa Timur. Semakin tinggi tingkat bahaya perubahan iklim mengandung arti bahwa kerugian/kehilangan produksi per luas lahan padi petani semakin besar. Tingginya tingkat bahaya perubahan pada petani padi Jawa Barat berpotensi memunculkan risiko (risks) berupa penurunan pasokan bahan makanan padi yang akan mengancam terganggunya ketahanan pangan dan neraca pangan mengingat Provinsi Jawa Barat salah satu kontributor utama komoditas padi di Indonesia. Merujuk kepada Ruminta (2011), besarnya tingkat bahaya perubahan iklim mengindikasikan semakin kecilnya pendapatan usahatani petani.

\section{Tingkat Kerentanan (Vulnerability)}

Perubahan Iklim pada Petani Padi di Jawa Barat dan Jawa Timur

Berdasarkan Tabel 3, hasil pengujian Mann Withney $U$ menunjukkan bahwa dengan tingkat kepercayaan 95\%, tingkat kerentanan perubahan iklim pada populasi petani padi Jawa Barat secara signifikan lebih rendah dari pada populasi petani padi Jawa Timur. Walaupun demikian, tingkat kerentanan perubahan iklim keduanya berada pada kategori rendah dengan nilai rata-rata 0,86 untuk Jawa Barat dan 0,98 untuk Jawa Timur. Setidaknya separih petani dari kedua provinsi tersebut memiliki tingkat kerentanan perubahan iklim pada kategori rendah.

Tabel 3. Tingkat Kerentanan (Vulnerability) Perubahan Iklim Petani Padi Jawa Barat dan Jawa Timur

\begin{tabular}{|c|c|c|c|c|}
\hline \multirow{2}{*}{$\begin{array}{c}\text { Tingkat } \\
\text { Kerentanan } \\
\text { Perubahan Iklim }\end{array}$} & \multicolumn{2}{|c|}{ Jawa Barat } & \multicolumn{2}{|c|}{ Jawa Timur } \\
\hline & $\mathrm{n}$ & $\%$ & $\mathrm{n}$ & $\%$ \\
\hline $\begin{array}{l}0<V_{i} \leq 1 \\
\text { (Rendah) }\end{array}$ & 195 & 65.00 & 176 & 58.67 \\
\hline $\begin{array}{l}1<V_{i} \leq 2 \\
\text { (Sedang) }\end{array}$ & 99 & 33.00 & 112 & 37.33 \\
\hline $\begin{array}{l}2<V_{i} \leq 3 \\
\text { (Tinggi) }\end{array}$ & 6 & 2.00 & 12 & 4.00 \\
\hline Jumlah (n) & 300 & 100 & 300 & 100 \\
\hline Maksimum & \multicolumn{2}{|c|}{2.21} & \multicolumn{2}{|c|}{2.96} \\
\hline Minimum & \multicolumn{2}{|c|}{0.15} & \multicolumn{2}{|c|}{0.13} \\
\hline Rata-rata & \multicolumn{2}{|c|}{0.86} & \multicolumn{2}{|c|}{0.98} \\
\hline Simp. Baku & \multicolumn{2}{|c|}{0.44} & \multicolumn{2}{|c|}{0.53} \\
\hline$p$-value & \multicolumn{4}{|c|}{$0.011 *$} \\
\hline $\begin{array}{r}\text { Ket: } * \text { Signifikan } \\
* * \text { Signifikan } \\
\text { sumber. data prim }\end{array}$ & (li & $\begin{array}{l}\text { yata } 5 \\
\text { yata } 1 \\
2020)\end{array}$ & & \\
\hline
\end{tabular}

Semakin kecil tingkat kerentanan yang dimiliki petani akan semakin mengurangi tingkat risiko petani tersebut terhadap perubahan iklim. Sehingga semakin banyak petani yang memiliki tingkat kerentanan rendah akan semakin mengurangi jumlah petani dengan tingkat risiko tinggi terhadap perubahan iklim. Meskipun sebagian besar petani padi di 
kedua provinsi memiliki tingkat kerentanan yang rendah, namun harus menjadi perhatian juga bahwa setidaknya terdapat $35 \%$ petani padi dari masingmasing provinsi yang tingkat kerentanan perubahan iklimnya sedang dan tinggi. Menurut Murniati (2020), perubahan iklim akan berdampak pada ketersediaan dan aksesibilitas pangan, sehingga mengganggu ketahanan pangan dan kerentanan rumah tangga petani. Merujuk kepada Harvey et al (2014) yang melakukan penelitian kerentanan perubahan iklim di Madagaskar meyatakan bahwa petani kecil sangat rentan terhadap guncangan apa pun terhadap sistem pertanian mereka karena ketergantungan mereka yang tinggi pada pertanian untuk mata pencaharian mereka, kerawanan pangan kronis, isolasi fisik dan kurangnya akses ke jaring pengaman formal. Para petani sering kali terpapar wabah hama dan penyakit serta peristiwa cuaca ekstrem (terutama siklon), yang menyebabkan hilangnya panen dan pendapatan yang signifikan serta memperburuk kerawanan pangan.

Kerentanan perubahan iklim dalam penelitian ini adalah gabungan dari tiga komponen kerentanan yaitu eksposur, sensitivitas dan kapasitas adaptasi. Kerentanan dihitung sebagai sebuah fungsi perkalian eksposur dengan sensitivitas dibagi kapasitas adaptif. Selanjutnya akan dibahas hasil mengenai tiga komponen kerentanan tersebut.

\section{Eksposur}

Eksposur merupakan tingkat keterpaparan petani padi oleh perubahan iklim. Berdasarkan Tabel 4 tingkat eksposur perubahan iklim petani padi Jawa Barat dan Jawa Timur sebagian besar berada pada kategori sedang. Hasil uji Mann Withney U menunjukkan bahwa tingkat eksposur perubahan iklim populasi petani Jawa Timur lebih tinggi dari populasi petani padi Jawa Barat secara signifikan dengan tingkat kepercayaan $99 \%$.

Tabel 4. Tingkat Eksposur Perubahan Iklim Petani Padi Jawa Barat dan Jawa Timur

\begin{tabular}{|c|c|c|c|c|}
\hline \multirow{2}{*}{$\begin{array}{c}\text { Tingkat } \\
\text { Eksposur } \\
\text { Perubahan Iklim }\end{array}$} & \multicolumn{2}{|c|}{ Jawa Barat } & \multicolumn{2}{|c|}{ Jawa Timur } \\
\hline & $\mathrm{n}$ & $\%$ & $\mathrm{n}$ & $\%$ \\
\hline $\begin{array}{l}0<E_{i} \leq 1 \\
\text { (Rendah) }\end{array}$ & 88 & 29.33 & 50 & 16.67 \\
\hline $\begin{array}{l}1<E_{i} \leq 2 \\
\text { (Sedang) }\end{array}$ & 196 & 65.33 & 211 & 70.33 \\
\hline $\begin{array}{l}2<E_{i} \leq 3 \\
\text { (Tinggi) }\end{array}$ & 16 & 5.33 & 39 & 13.00 \\
\hline Jumlah (n) & 300 & 100 & 300 & 100 \\
\hline Maksimum & \multicolumn{2}{|c|}{2.75} & \multicolumn{2}{|c|}{2.50} \\
\hline Minimum & \multicolumn{2}{|c|}{0.25} & \multicolumn{2}{|c|}{0.50} \\
\hline Rata-rata & \multicolumn{2}{|c|}{1.32} & \multicolumn{2}{|c|}{1.51} \\
\hline Simp. Baku & \multicolumn{2}{|c|}{0.50} & \multicolumn{2}{|c|}{0.44} \\
\hline$p$-value & \multicolumn{4}{|c|}{$0.000 * *$} \\
\hline
\end{tabular}

Untuk mengurangi tingkat eksposur perubahan iklim maka yang harus 
dioptimalkan diantarnya adalah jenis dan asal varietas padi, jumlah tanggungan keluarga dan penanganan hama padi. Hal tersebut dapat diupayakan diantaranya dengan mengoptimalkan penggunaan benih formal maupun informal yang berkualitas dan dapat beradaptasi dengan perubahan iklim (Firdaus et al., 2020), meningkatkan kapasitas petani kecil sehingga bisa meningkatkan penghasilan keluarga (Aminah, 2015), serta penggunaan teknologi penanganan hama yang adaptif perubahan iklim (Widiarta, 2016).

\section{Sensitifitas}

Sensitifitas dalam penelitian ini merupakan dimensi usahatani yang secara lengsung mudah terdampak oleh perubaham iklim. Berdasarkan Tabel 5, hasil uji Mann Withney U menunjukkan bahwa tidak terdapat perbedaan tingkat sensititifitas perubahan iklim antara populasi petani Jawa Timur dan populasi petani padi Jawa Barat. Tingkat sensititifitas perubahan iklim petani padi Jawa Barat dan Jawa Timur sebagian besar berada pada kategori rendah dan sedang.

Indikator sensitifitas perubahan iklim pada penelitian ini berkaitan dengan biaya faktor produksi seperti biaya tenaga kerja, biaya input dan biaya irigasi serta harga jual yang hilang. Tingkat sensitifitas perubahan iklim yang berada pada kategori rendah dan sedang tersebut menunjukkan bahwa biaya produksi sudah cukup efisien dan akses pasar sudah cukup baik.

Tabel 5. Tingkat Sensitifitas Perubahan Iklim Petani Padi Jawa Barat dan Jawa Timur

\begin{tabular}{|c|c|c|c|c|}
\hline \multirow{2}{*}{$\begin{array}{c}\text { Tingkat } \\
\text { Sensitifitas } \\
\text { Perubahan Iklim }\end{array}$} & \multicolumn{2}{|c|}{ Jawa Barat } & \multicolumn{2}{|c|}{ Jawa Timur } \\
\hline & $\mathrm{n}$ & $\%$ & $\mathrm{n}$ & $\%$ \\
\hline $\begin{array}{l}0<S_{i} \leq 1 \\
\text { (Rendah) }\end{array}$ & 127 & 42.33 & 140 & 46.67 \\
\hline $\begin{array}{l}1<S_{i} \leq 2 \\
\text { (Sedang) }\end{array}$ & 171 & 57.00 & 135 & 45.00 \\
\hline $\begin{array}{l}2<S_{i} \leq 3 \\
\text { (Tinggi) }\end{array}$ & 2 & 0.67 & 25 & 8.33 \\
\hline Jumlah (n) & 300 & 100 & 300 & 100 \\
\hline Maksimum & \multicolumn{2}{|c|}{2.50} & \multicolumn{2}{|c|}{2.50} \\
\hline Minimum & \multicolumn{2}{|c|}{0.25} & \multicolumn{2}{|c|}{0.25} \\
\hline Rata-rata & \multicolumn{2}{|c|}{1.21} & \multicolumn{2}{|c|}{1.24} \\
\hline Simp. Baku & \multicolumn{2}{|c|}{0.50} & \multicolumn{2}{|c|}{0.60} \\
\hline p-value & \multicolumn{4}{|c|}{0.798} \\
\hline $\begin{aligned} \text { Ket: } & * \text { Signifika } \\
& * * \text { Signifika }\end{aligned}$ & 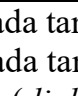 & f nyata & & \\
\hline
\end{tabular}

\section{Kapasitas Adaptasi}

Tingkat kapasitas adaptasi petani terhadap perubahan iklim dihitung dari rata-rata dari skor indikator-indikatornya yaitu usia, pendidikan, pengalaman berusahatani, frekuensi mengikuti pelatihan pertanian, curahan kerja, luas lahan, tingkat kesuburan tanah dan kondisi irigasi petani. Berdasarkan Tabel 6, tingkat kapasitas adaptasi perubahan iklim petani padi Jawa Barat dan Jawa Timur berada pada kategori sedang dan tinggi. Hasil uji Mann Withney U 
menunjukkan bahwa tingkat kapasitas adaptasi perubahan iklim populasi petani Jawa Timur lebih tinggi dari populasi petani padi Jawa Barat secara signifikan dengan tingkat kepercayaan $99 \%$.

Tabel 6. Tingkat Kapasitas Adaptasi Perubahan Iklim Petani Padi Jawa Barat dan Jawa Timur

\begin{tabular}{|c|c|c|c|c|}
\hline \multirow{2}{*}{$\begin{array}{c}\text { Tingkat } \\
\text { Kapasitas } \\
\text { Adaptasi } \\
\text { Perubahan Iklim }\end{array}$} & \multicolumn{2}{|c|}{ Jawa Barat } & \multicolumn{2}{|c|}{ Jawa Timur } \\
\hline & $\mathrm{n}$ & $\%$ & $\mathrm{n}$ & $\%$ \\
\hline $\begin{array}{l}0<A C_{i} \leq 1 \\
\text { (Rendah) }\end{array}$ & 0 & 0.00 & 0 & 0.00 \\
\hline $\begin{array}{l}1<A C_{i} \leq 2 \\
\text { (Sedang) }\end{array}$ & 283 & 94.33 & 265 & 88.33 \\
\hline $\begin{array}{l}2<A C_{i} \leq 3 \\
\text { (Tinggi) }\end{array}$ & 17 & 5.67 & 35 & 11.67 \\
\hline Jumlah (n) & 300 & 100 & 300 & 100 \\
\hline Maksimum & \multicolumn{2}{|c|}{2.22} & \multicolumn{2}{|c|}{2.33} \\
\hline Minimum & \multicolumn{2}{|c|}{1.11} & \multicolumn{2}{|c|}{1.33} \\
\hline Rata-rata & \multicolumn{2}{|c|}{1.78} & \multicolumn{2}{|c|}{1.86} \\
\hline Simp. Baku & \multicolumn{2}{|c|}{0.17} & \multicolumn{2}{|c|}{0.18} \\
\hline p-value & \multicolumn{4}{|c|}{$0.000 * *$} \\
\hline $\begin{aligned} \text { Ket: } & * \text { Signifik } \\
& * * \text { Signifik }\end{aligned}$ & a & $\begin{array}{l}\text { If ny } \\
\text { if ny }\end{array}$ & $\begin{array}{l}5 \% \\
1 \%\end{array}$ & \\
\hline
\end{tabular}

Semakin besar tingkat kapasitas adaptasi yang dimiliki petani akan semakin mengurangi tingkat kerentanan dan risiko petani tersebut terhadap perubahan iklim. Sehingga semakin banyak petani yang memiliki kapasitas adaptasi tinggi akan semakin mengurangi jumlah petani dengan tingkat risiko dan kerentanan tinggi terhadap perubahan iklim. Upaya-upaya berikut dapat dilakukan untuk lebih meningkatkan kapasitas adaptasi perubahan iklim petani, diantaranya regenerasi petani,

pelatihan tani, peningkatan kesuburan lahan, perbaikan irigasi dan meningkatkan alternatif pekerjaan sampingan selain bertani padi.

\section{Tingkat Risiko (Risk) Perubahan Iklim} pada Petani Padi di Jawa Barat dan Jawa Timur

Berdasarkan Tabel 7, hasil uji Mann Withney U menunjukkan bahwa tidak terdapat perbedaan tingkat risiko perubahan iklim antara populasi petani Jawa Timur dan populasi petani padi Jawa Barat. Tingkat sensititifitas perubahan iklim petani padi Jawa Barat dan Jawa Timur sebagian besar berada pada kategori rendah dan sisanya berada pada kategori sedang.

Tabel 7. Tingkat Risiko (Risk) Perubahan Iklim Petani Padi Jawa Barat dan Jawa Timur

\begin{tabular}{|c|c|c|c|c|}
\hline \multirow{2}{*}{$\begin{array}{l}\text { Tingkat Risiko } \\
\text { Perubahan Iklim }\end{array}$} & \multicolumn{2}{|c|}{ Jawa Barat } & \multicolumn{2}{|c|}{ Jawa Timur } \\
\hline & $\mathrm{n}$ & $\%$ & $\mathrm{n}$ & $\%$ \\
\hline $\begin{array}{l}0<R_{i} \leq 1 \\
\text { (Rendah) }\end{array}$ & 258 & 86.00 & 257 & 85.67 \\
\hline $\begin{array}{l}1<R_{i} \leq 2 \\
\text { (Sedang) }\end{array}$ & 42 & 14.00 & 43 & 14.33 \\
\hline $\begin{array}{l}2<R_{i} \leq 3 \\
\text { (Tinggi) }\end{array}$ & 0 & 0.00 & 0 & 0.00 \\
\hline Jumlah (n) & 300 & 100 & 300 & 100 \\
\hline Maksimum & \multicolumn{2}{|c|}{1.75} & \multicolumn{2}{|c|}{1.92} \\
\hline Minimum & \multicolumn{2}{|c|}{0.10} & \multicolumn{2}{|c|}{0.00} \\
\hline Rata-rata & \multicolumn{2}{|c|}{0.62} & \multicolumn{2}{|c|}{0.64} \\
\hline Simp. Baku & \multicolumn{2}{|c|}{0.33} & \multicolumn{2}{|c|}{0.34} \\
\hline$p$-value & \multicolumn{4}{|c|}{0.529} \\
\hline $\begin{array}{r}\text { Ket: } * \text { Signifika } \\
* * \text { Signifika } \\
\text { sumber: data pri }\end{array}$ & add & af nyat & $\begin{array}{l}5 \% \\
1 \%\end{array}$ & \\
\hline
\end{tabular}


Banyaknya petani yang memiliki tingkat risiko perubahan iklim pada kategori rendah terutama disebabkan oleh banyaknya petani yang memiliki tingkat kerentanan rendah dan sangat rendah yang berhasil mengurangi banyaknya petani yang mempunyai tingkat bahaya tinggi dan sangat tinggi. Sementara itu, petani dengan tingkat risiko sedang disebabkan oleh tingkat bahaya perubahan iklimnya yang tinggi.

Merujuk kepada Rochdiani dkk. (2017), petani yang mempunyai tingkat risiko perubahan iklim tinggi dan sedang, didominasi oleh petani yang mempunyai lahan di atas 1 hektar, sedangkan petani yang mempunyai tingkat risiko perubahan iklim rendah kebanyakan adalah petani yang mempunyai luas lahan di bawah 1 hektar.

\section{KESIMPULAN DAN SARAN}

Petani Jawa Barat lebih banyak yang memiliki tingkat bahaya (hazard) perubahan iklim pada kategori tinggi dibandingkan petani padi Jawa Timur, sedangkan berdasarkan tingkat kerentanannya (vulnerability), petani padi Jawa Barat lebih banyak yang memiliki tingkat kerentanan terhadap perubahan iklim pada kategori rendah dari pada petani padi Jawa Tumur. Berdasarkan indikator kerentananya, petani padi di Jawa Timur memiliki tingkat eksposur, sensitifitas dan kepasitas adaptasi dari lebih tinggi dari petani padi Jawa Barat.

Petani padi di Jawa Barat memiliki tingkat bahaya perubahan iklim yang lebih besar secara signifikan ketimbang petani padi di Jawa Timur, namun petani padi di Jawa Barat memiliki tingkat kerentanan perubahan iklim yang lebih rendah secara signifikan dibandingkan petani padi di Jawa Timur. Sehingga hasil analisis tingkat risiko perubahan iklim menunjukkan bahwa tidak terdapat perbedaan yang signifikan antara petani Jawa Barat dan Jawa Timur dalam hal tingkat risiko perubahan iklimnya. Keduanya sama-sama memiliki tingkat risiko perubahan iklim yang berada pada kategori rendah hingga sedang.

Untuk mengurangi dampak dari risiko perubahan iklim, berbagai indikator bahaya dan kerentanan perubahan iklim pada petani padi harus diminimalisasi serta kapasitas adaptasi perubahan iklim petani harus ditingkatkan. Upaya tersebut dapat diwujudkan diantaranya dengan meningkatkan kualitas benih padi, penanganan hama yang tepat, efisiensi biaya produksi, peningkatan akses pasar, regenerasi petani, pelatihan tani, 
meningkatkan kesuburan lahan, perbaikan irigasi dan meningkatkan alternatif pekerjaan sampingan selain bertani padi.

\section{DAFTAR PUSTAKA}

[IPCC] Change, I. P. O. C. (2001). Climate change 2007: Impacts, adaptation and vulnerability. Genebra, Suiça.

Affeltrnger, B. Alcedo., Amman, WJ, Arnold, M.(2006). Living with Risk, "A Global Review of Disaster Reduction Initiatives.

Aminah, S. (2015). Pengembangan kapasitas petani kecil lahan kering untuk mewujudkan ketahanan pangan. Jurnal Bina Praja: Journal of Home Affairs Governance, 7(3), 197-210.

Anderson, D. R., Sweeney, D. J., Williams, T. A., Camm, J. D., \& Cochran, J. J. (2016). Statistics for business \& economics. Nelson Education.

Beck, S., \& Mahony, M. (2018). The IPCC and the new map of science and politics. Wiley Interdisciplinary Reviews: Climate Change, 9(6), e547.

Cahyaningtyas, A., Azizah, N., \& Herlina, N. (2019). Evaluasi Dampak Perubahan Iklim terhadap Produktivitas Padi (Oryza sativa L.) di Kabupaten Gresik. Jurnal Produksi Tanaman, 6(9).

Creswell, J. W., \& Clark, V. L. P. (2017). Designing and conducting mixed methods research. Sage publications.

Crichton, D. (1999). Natural disaster management. The Risk triangle. Tudor Rose, Leicester.

Firdaus, D., Natawidjaja, R. S., \& Rachmady, M. (2020).
Strengthening of the Formal Complementary Paddy Seeding System and Informal to Fulfill Demand of Quality Paddy Seeds and to Develop Seed Farming Business in West Java. In E3S Web of Conferences (Vol. 142, p. 06001). EDP Sciences.

Gommes, R. (1998, April). Climaterelated risk in agriculture. In IPCC Expert Meeting on Risk Management Methods (p. 13).

Handoko, I., Sugiarto, Y., \& Syaukat, Y. (2008). Keterkaitan perubahan iklim dan produksi pangan strategis. Telaah kebijakan independen bidang perdagangan dan pembangunan oleh kemitraan/partnership Indonesia. SEAMEO BIOTROP. Bogor, 34-56.

Harvey, C. A., Rakotobe, Z. L., Rao, N. S., Dave, R., Razafimahatratra, H., Rabarijohn, R. H., ... \& MacKinnon, J. L. (2014). Extreme vulnerability of smallholder farmers to agricultural risks and climate change in Madagascar. Philosophical Transactions of the Royal Society B: Biological Sciences, 369(1639), 20130089.

Li, C., Ting, Z., \& Rasaily, R. G. (2010). Farmer's Adaptation to Climate Risk in the Context of China-: A research on Jianghan Plain of Yangtze River Basin. Agriculture and Agricultural Science Procedia, 1, 116-125.

Murniati, K. (2020). The impact of climate change on the household food security of upland rice farmers in Sidomulyo, Lampung Province, Indonesia. Biodiversitas Journal of Biological Diversity, 21(8).

Natawidjaja, R. S., Supyandi, D., Tulloh, C., Tridakusumah, A. C., Calford, E. M., \& Ford, M. (2009). Climate Change, Food Security and Income Distribution: Adaptations of Small 
Rice Farmers. Crawford School of Economics and Government at The Australian National University, Canberra.

Nuraisah, G., \& Kusumo, R. A. B. (2019). Dampak perubahan iklim terhadap usahatani padi di desa Wanguk kecamatan Anjatan kabupaten Indramayu. Mimbar Agribisnis: Jurnal Pemikiran Masyarakat Ilmiah Berwawasan Agribisnis, 5(1), 60-71.

Rasmikayati, E., \& Djuwendah, E. (2015). Dampak perubahan iklim terhadap perilaku dan pendapatan petani (the impact of climate change to farmers' behavior and revenue). Jurnal Manusia Dan Lingkungan, 22(3), 372-379.

Rasmikayati, E., Djuwendah, E., Mukti, G. W., \& Rachmat, B (2017). Analisis Strategi Adaptasi Terhadap Perubahan Iklim Pada Petani Padi Di Jawa Barat.

Rasmikayati, E., Saefudin, B. R., Rochdiani, D., \& Natawidjaja, R. S. (2020). Dinamika Respons Mitigasi Petani Padi di Jawa Barat dalam menghadapi Dampak Perubahan Iklim serta Kaitannya dengan Pendapatan Usahatani. Jurnal Wilayah dan Lingkungan, 8(3).

Rochdiani, D., Kuswarini, K., \& Bobby, R. S. (2017). Risiko Perubahan Iklim Serta Pengaruhnya Terhadap Pendapatan Petani Usahatani Padi di Jawa Barat. In Prosiding Seminar Nasional Mitigasi dan Strategi Adaptasi Dampak Perubahan Iklim di Indonesia. Pekanbaru (ID): Universitas Islam Riau.
Ruminta, R. (2015). Dampak perubahan iklim pada produksi apel di Batu Malang Impacts of climate change on production of apple in Batu Malang. Kultivasi, 14(2).

Ruminta. (2011). Kajian Kerentanan, Risiko dan Adaptasi Perubahan Iklim pada Sektor Pertanian di Kabupaten Bandung. Jakarta: Universitas Padjadjaran.

Rygel, L., O'sullivan, D., \& Yarnal, B. (2006). A method for constructing a social vulnerability index: an application to hurricane storm surges in a developed country. Mitigation and adaptation strategies for global change, 11(3), 741-764.

Saefudin, B. R. (2014). Risiko Perubahan Iklim Dan Strategi Adaptasi Petani Padi Serta Pengaruhnya Terhadap Pendapatan Petani (Suatu Kasus Di Jawa Barat Dan Jawa Timur).

Setiani, P. (2020). Sains Perubahan Iklim. Bumi Aksara.

Sudarma, I. M., \& As-syakur, A. R. (2018). Dampak perubahan iklim terhadap sektor pertanian di Provinsi Bali. SOCA: Jurnal Sosial Ekonomi Pertanian, 87-98.

Sumastuti, E., \& Pradono, N. S. (2016). Dampak perubahan iklim pada tanaman padi di Jawa Tengah. Journal of Economic Education, 5(1), 31-38.

Widiarta, I. N. (2016). Teknologi Pengelolaan Tanaman Pangan dalam Beradaptasi Terhadap Perubahan Iklim pada Lahan Sawah. 